\title{
Development of a method for monitoring and control of the process of production localization regarding power engineering
}

\author{
$V Y$ Bauer* $^{*}$ and $D G$ Shuvalova \\ Department of Economics in Energy and Industry, Moscow Power Engineering Institute, Krasnokazarmennaya 14, Moscow, 111250 \\ Russia
}

\begin{abstract}
This article describes the problem of monitoring and control of the process of production localization regarding power engineering industry. In this research, the authors identified an additional factor for assessing the level of localization of the power engineering industry, which takes into account the specifics of the industry. The authors also developed a method for monitoring and controlling the process of localizing production at various stages of the application of this strategy.
\end{abstract}

\section{Introduction}

One of the methods for controlling the flow of slurry is In the contest of today's world economy, the Government of the Russian Federation, together with the Ministry of Industry and Trade of the Russian Federation and the manufacturing enterprises more and more often use localization of production as a specific type of strategy of import substitution, and among the objectives of the state policy is to increase the industry competitiveness, including power engineering. Therefore, one of the main goals of industrial production in the territory of the Russian Federation is to achieve the maximum level of localization of production (up to one hundred percent in certain areas of power engineering). [1,2,3,4]

Localization of production is essentially a process of establishment of a new production site in the country using production areas, local raw materials, and supplies normally powered by foreign technology. At the same time, it is a complex process that requires special attention and control by the state, an example of which can be the experience of various countries applying the strategy of localization (China, Uzbekistan, Italy, Germany) [13, 14].

The localization level ranging from 0 to 100 percent is used to manage and monitor the implementation of localization strategies. The localization level is used as an indicator of the share of cost generated in the territory of the country and, therefore, can be interpreted as a tool for controlling the stages of import substitution policy implementation.

The level of localization itself represents the share of the added value created in the national territory in the cost of the product or in the proceeds received from its sale. At the moment there are about nine [2-8] different methods for assessing the level of localization for various industries.
Methods for assessing the level of localization differ by the degree of complexity, the number of data sources required for the calculations, their availability. More labor-intensive techniques take into account localization of R\&D, which is certainly an important part of the production localization, but none of them is devoid of the error of analysis associated with features of the system for accounting results of intellectual activity in Russia.

In fact, nowadays there is no universal method of assessing the level of localization, which is due to both industry-specific features of production and accounting system and in some cases the value chain itself.

Electrical and power engineering are materialintensive production areas [15]. For some types of products, the share of materials' costs in the price of manufactured equipment reaches $60-70 \%$.

In order to calculate the level of localization of production for electrical and power engineering enterprises, it is necessary to introduce a coefficient that takes into account the share of the cost of imported raw materials, supplies and components in total material costs.

Thus, it is proposed to introduce a correction coefficient of $1 / \alpha$ into the existing formula for calculating the localization level.

$$
\alpha=\left(1+\frac{K_{i m p}}{K_{\Sigma}}\right),
$$

where $K_{\text {imp }}$ is the cost of imported raw materials, supplies and components used in equipment and having domestic equivalents, RUB; $K_{\Sigma}$ is the total cost of raw materials, supplies, and components used in the specified equipment, RUB.

Application of this coefficient to calculation of the level of localization stimulates manufacturers to use existing domestic equivalents of imported raw materials,

\footnotetext{
* Corresponding author: kuznetsovavika5@mail.ru
} 
supplies and components: if all imported components have domestic equivalents and the manufacturer continues to purchase components abroad, the level of localization reduces by 2 times. Figure 1 shows the dependence of the correction coefficient (Koef) on the share of domestic raw materials, supplies, and components used in the equipment, in the total cost of material costs $(\mathrm{Kl})$ provided that all imported components have domestic equivalents.

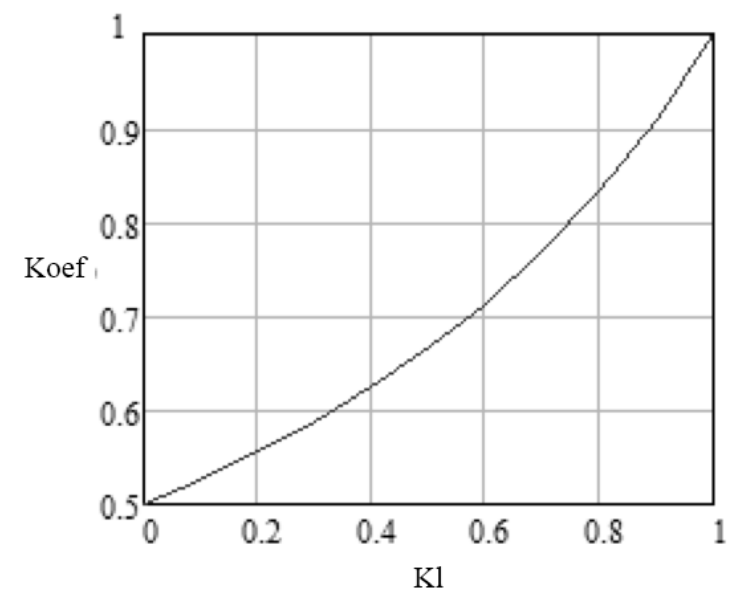

Fig. 1. Dependence of the correction coefficient on the share of domestic raw materials.

As can be seen from the graph, the correction coefficient can take values from 0.5 to 1 .

The consideration of existing domestic equivalents assumes the existence of similarity criteria, according to which certain domestic components can be recognized as analogs of the foreign ones: the purpose, the similarity of the set of essential features. Significant features include the specific weight of nutrients in raw materials, strength, productivity, etc. Similarity implies setting ranges of allowable differences. In addition to the criteria of similarity, it is necessary to constantly monitor the market, which should be the responsibility of the state authorities controlling the localization process. A systematic approach to the process will balance the interests of host and incoming parties [12]. Despite a number of difficulties, due to a systematic approach to assessing the level of localization, the proposed changes allow achieving a greater effect from the implementation of the strategy of production localization.

Thus, the proposed methodology is as follows:

$$
l=\frac{1-\frac{V}{P}}{1+\frac{K_{i m p}}{K_{\Sigma}}} \times 100 \%,
$$

where $V$ - cost of imported raw materials, supplies, components, OT of non-residents, etc. (instead of used customs value), RUB;

$P$ - price of final products, RUB;
$K_{\text {imp }}$ - cost of imported raw materials, supplies and components used in equipment and having domestic equivalents, RUB;

$K_{\Sigma}$ - total cost of raw materials, supplies, and components used in the specified equipment, RUB.

Calculation of the level of production localization is carried out in the currency of the Russian Federation in the actual transfer (selling) prices excluding VAT. The actual transfer (selling) prices are the prices at which the Russian legal entity actually sold the equipment produced by it.

Within the framework of the study, a graphical presentation of the data on the process of localization of production in the country is proposed.

In accordance with the established approach of cost formation, two types of localization by the depth of coverage of cost items can be identified: localization which mainly affects one of the cost items (payroll, materials, equipment, intellectual capital) or any combination thereof.

When monitoring the implementation of import substitution programs and assessing the changes in the level of localization, it is necessary to control specific components of the cost (raw materials, equipment, labor). Figure 2 is a graphical interpretation of the uniformity of localization by cost items expressed in the angle of the vector constructed by their points in the axes where vertical and horizontal lines show the levels of achieved localization by individual cost items. A complete map of the achieved localization parameters is obtained by constructing all vectors of pairwise comparison for all investigated items of prime cost.

The functions of the state include control and management of the localization process, which allows preventing speculation in domestic markets, price inflation, reduction of economic security, and enables planning intersectoral balance sheets for resource production.

Graphic and analytical methods can serve as control tools. Based on the obtained data, a coordinate system is constructed, along the axes of which localization levels for individual items of cost are put. The uniformity of the localization is determined by the direction of the line that passes through the origin point and the point of intersection of the localization levels. For example, Figure 2 shows a coordinate system that allows determining the uniformity of localization by material costs and payroll. Research and analysis can be carried out in any two directions in pairs, or in three of them, by building vectors in space. The process is considered uniform when $\mathrm{Ll}_{\mathrm{mc}}=\mathrm{Ll}_{\mathrm{sf}}$. Hence the condition of uniformity of localization is:

$$
\alpha \rightarrow 45^{\circ} \text { or }\left(\alpha-45^{\circ}\right) \rightarrow 0^{\circ}
$$




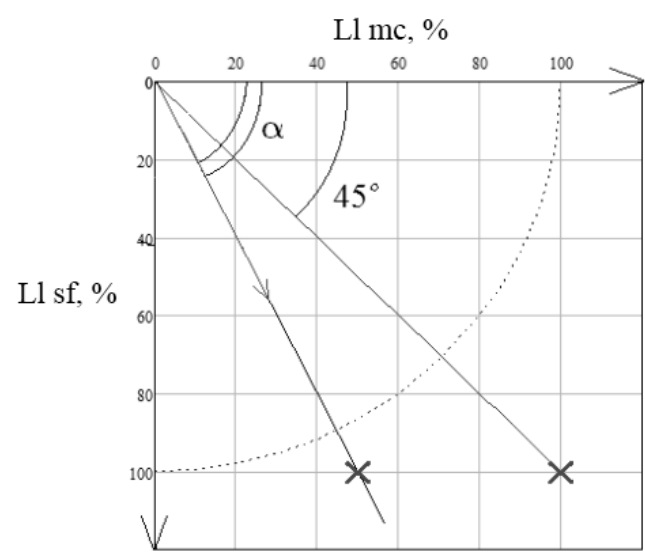

Fig. 2. The uniformity of localization by material costs and payroll.

Like any vector, the localization vector is characterized by length and direction. The vector length is the value of the localization level calculated using one of the estimation methods, the direction is determined by the value of the angle $\alpha$.

Figure 3 shows the coordinate system for determining the uniformity of localization by material costs, payroll, and depreciation: localization levels are compared in pairs by individual cost items.

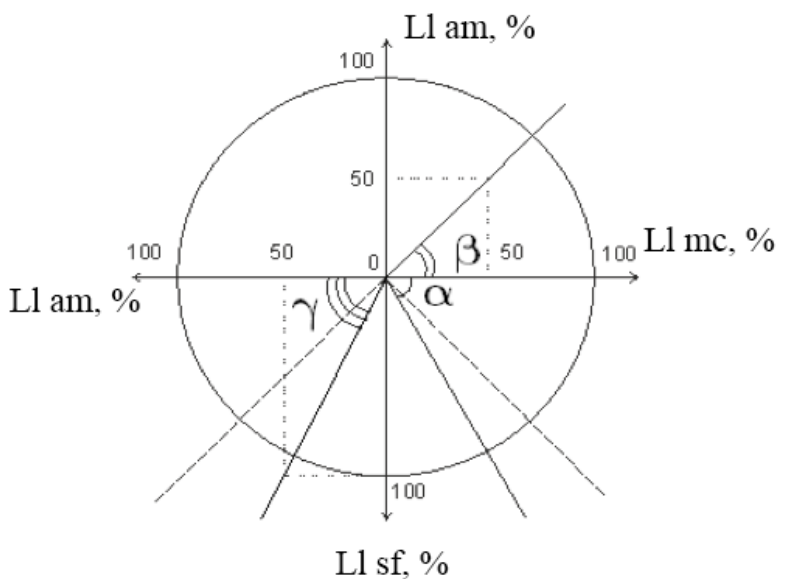

Fig. 3. The uniformity of localization by material costs, payroll and depreciation.

The graph of accounting of the localization level uniformity in Figure 3 shows only three components that affect the localization level of production, but as noted above, it is necessary to consider four indicators, the fourth of which should be intellectual property. In order to compare the first three indicators of the localization level with intellectual property, it is required to construct a two-dimensional vector for each case under consideration. Thus, a universal method of monitoring and control of the localization process is developed, taking into account the uniformity of localization by cost items and the final value of the investigated level.

Strategically important for the power engineering enterprises is the fulfillment of their obligations to the energy sector which makes the process of value generation control more significant in the country. Production localization programs should be performed in time, in accordance with the terms stipulated by the state policy and strategies of the companies, so the method of assessing the level of localization for the power engineering industry can be one of the ways to control this process.

\section{References}

1. Prikaz Minpromtorga RF N 206 ot 22.02.2011g. «Ob utverzhdenii strategii razvitiya energomashinostroyeniya Rossiyskoy Federatsii na 2010 - 2020 gody i na perspektivu do 2030 goda».

2. Proyekt postanovleniya Pravitelstva RF «O prioritetnom ispolzovanii otechestvennogo oborudovaniya».

3. Prikaz Minekonomrazvitiya RF N 678, Minpromtorga RF N 1289, Minfina RF N 184n ot 24.12.2010 g. "O vnesenii izmeneniy v poryadok, opredelyayushchiy ponyatiye "promyshlennaya sborka" motornykh transportnykh sredstv i ustanavlivayushchiy primeneniye dannogo ponyatiya pri vvoze na territoriyu Rossiyskoy Federatsii avtokomponentov dlya proizvodstva motornykh transportnykh sredstv tovarnykh pozitsiy 8701 - 8705 TN VED, ikh uzlov i agregatov".

4. Postanovlenie Pravitelstva Rossiiskoi Federazcii ot 25.01.19 №43 «O provedenii otborov po modernizacii generiruyushih obektov teplovih eletrostancii»

5. Prikaz Minpromtorga Rossii N 1032, Minekonomrazvitiya Rossii N 397 ot 17.08.2011 (red. ot 29.10.2013) "Ob utverzhdenii parametrov, v sootvetstvii so znacheniyami kotorykh telekommunikatsionnomu oborudovaniyu, proizvedennomu na territorii Rossiyskoy Federatsii, mozhet byt prisvoyen status telekommunikatsionnogo oborudovaniya rossiyskogo proiskhozhdeniya, metodiki opredeleniya znacheniy parametrov, $\mathrm{v}$ sootvetstvii s kotorymi telekommunikatsionnomu oborudovaniyu, proizvedennomu na territorii Rossiyskoy Federatsii, mozhet byt prisvoyen status telekommunikatsionnogo oborudovaniya rossiyskogo proiskhozhdeniya, poryadka prisvoyeniya telekommunikatsionnomu oborudovaniyu, proizvedennomu na territorii Rossiyskoy Federatsii, statusa telekommunikatsionnogo oborudovaniya rossiyskogo proiskhozhdeniya i yezhegodnogo podtverzhdeniya takogo statusa".

6. S. Aleshin, S. Portnoy, Rossiyskiy proizvoditel kto on? Praktika sozdaniya i metodologiya opredeleniya, ELEKTRONIKA: Nauka, Tekhnologiya, Biznes, 6, 7 (2010)

7. I.O. Volkova, D.G. Shuvalova, D.A. Smirnov, Metody lokalizatsii proizvodstva oborudovaniya $\mathrm{i}$ tekhnologiy v sisteme strategicheskogo upravleniya elektrosetevoy kompaniyey Korporativnoye 
upravleniye i innovatsionnoye razvitiye, Severa Vestnik Nauchno-issledovatelskogo tsentra korporativnogo prava, upravleniya i venchurnogo investirovaniya Syktyvkarskogo gosudarstvennogo universiteta, 1 (2012)

8. A. Mikhaylov, Malaya energetika Rossii: klassifikatsiya, zadachi, primeneniye, Novosti elektrotekhniki, 5 (2005)

9. A.N. Nichiporenko, Lokalizatsiya po zakonam globalizatsii, 4 (2011)

10. Sayt kompanii FINMANCONSULT: pasport proyekta lokalizatsii [Elektronnyy resurs] - Rezhim dostupa: http://fmc.uz/legisl.php?lok=por_vnes_korr_4.

11. D.G. Shuvalova, V.Yu. Markova, Otsenka izmeneniya ekonomicheskogo potentsiala integratsii $\mathrm{s}$ primeneniyem strategii lokalizatsii proizvodstva na regionalnom urovne, Upravlenie ekonomicheskimi sistemami, 10, 61 (2013)

12. D.F. Chichigin, Energeticheskoye mashinostroyeniye. Vozmozhnosti Rossii, Prezentatsiya, 10 (2013)

13. Zakon Kitaya (KNR) o sovmestnykh predpriyatiyakh s inostrannym kapitalom

14. Postanovleniye Prezidenta Respubliki Uzbekistan «O programme lokalizatsii proizvodstva gotovoy produktsii, komplektuyushchikh izdeliy i materialov na baze mestnogo syrya na 2006-2008 gody».

15. I.O. Volkova, Ye.A. Salnikova, S.G. Pukhov, D.M. Brodov, Analiz sostoyaniya rynka energomashinostroyeniya $\mathrm{v}$ Rossii, Energetika segodnya, 4/5, 34-38 (2010) 